\title{
Assessment of vibration induced white finger: reliability and validity of two tests
}

\author{
M HACK, ${ }^{1}$ M-A BOILLAT, ${ }^{1}$ C SCHWEIZER, ${ }^{2}$ AND M LOB ${ }^{1}$
}

From the Institute of Occupational Health and Industrial Hygiene, ${ }^{1}$ University of Lausanne, 1005 Lausanne, and $\vec{\circ}$ the Occupational Health and Industrial Hygiene Service, ${ }^{2} 2000$ Neuchâtel, Switzerland

ABSTRACT The reliability and validity of two tests (cold water and reactive hyperaemia) designed to confirm a patient's history of vibration induced white finger were studied. The cold water test is a measure of digital rewarming after hand immersion in cold water. Reactive hyperaemia consists of ct measuring digital rewarming after cold water immersion plus temporary ischaemia imposed on the $\vec{i}$ hand. For ten weeks, ten healthy male volunteers were submitted once a week to both tests to study $\stackrel{\infty}{\oplus}$ their reliability. The results showed a strong inter and intraindividual scattering. The mean value for 은 the whole group, however, did not differ significantly from one week to the next. Fifty two subjects exposed to hand/arm vibration were submitted to both tests to estimate their validity. They were $\frac{D}{0}$ classified, according to their medical history, into three groups: $\mathrm{A}=$ no symptoms, $\mathrm{B}=$ tingling or numbess, or both, $\mathrm{C}=$ Raynaud's phenomenon. Both tests agreed with the clinical staging. For $\vec{\oplus}$ reactive hyperaemia, however, the differences between the groups were statistically significant only $\%$ when the test was performed at $10^{\circ} \mathrm{C}$. These tests are more useful to study a group than an individual case. Time has no significant effect on the mean result of a group.

Numerous tests have been described to confirm a patient's history of vibration white finger (VWF), ${ }^{1-7}$ but their reliability has not been properly examined. Therefore it was decided, firstly, to estimate the reliability of two tests among non-exposed subjects and, secondly, their validity among a group of workers exposed to different sources of hand arm vibration. The test chosen, cold water, thoroughly described by Fawer $^{8}$ and reactive hyperaemia, described by Krähenbüh ${ }^{9}$ are easy to perform and may therefore be of use in the daily work of an industrial medicine outpatient department.

\section{Material and methods}

COLD WATER TEST

The cold water test is based on the theory that after immersion in cold water digital rewarming is slower in a subject suffering from VWF than in a normal subject.

The subject is tested sitting. After 15 minutes adaptation to the surrounding temperature (room $\mathrm{T}^{\circ}$ was

This paper is dedicated to the late R F Fawer, MD, MS, who took an active part in this study.

Accepted 9 September 1985 always kept between $20^{\circ}$ and $22^{\circ} \mathrm{C}$ ) thermocouples $\frac{0}{\mathrm{Q}}$ (Ellab AH-9) are attached to the ventral surface of the $\cong$ ring and forefingers of both hands, which are then $\overrightarrow{\overrightarrow{0}}$ submerged for 15 minutes in water at temperature 3 $\left(\mathrm{T}^{\circ}\right)$ of $5^{\circ}$ to $7^{\circ} \mathrm{C}$. The hands are then lightly dried and fingertip rewarming is measured for 20 minutes, using an Ellab thermometer (DU-35 type, 5 measure channels).

\section{REACTIVEHYPERAEMIA TEST}

The theory underlying this test is as follows. Reactive $\stackrel{\delta}{\partial}$ hyperaemia should take place after a period of ischaemia imposed on a finger. Raynaud's phenom- 을 enon is due to a spasm of the digital arteries, mainly $>$ in relation to cold. It is reasonable to suppose that for patients suffering from Raynaud's phenomenon there is a critical temperature at which the arteries collapse, $\Omega$ therefore abolishing or at least weakening reactive $N$ hyperaemia.

The subject sits to be tested. After 15 minutes adaptation to the surrounding $\mathrm{T}^{\circ}\left(20^{\circ}-22^{\circ} \mathrm{C}\right)$ thermocouples are attached to the same fingers and in the $\frac{}{\circ}$ same way as for the cold water test. A blood pressure $\stackrel{\odot}{\rightarrow}$ cuff is placed around both the subject's wrists and 0 inflated above the systolic pressure. Both hands are then submerged in a water bath cooled at $15^{\circ} \mathrm{C}$. After five minutes ischaemia, the base line $\mathrm{T}^{\circ}$ for each finger 
Table 1 Clinical classification

\begin{tabular}{llll}
\hline Group & $\begin{array}{l}\text { No of } \\
\text { subjects }\end{array}$ & Clinical signs & $\begin{array}{l}\text { Staging according to } \\
\text { Taylor and } \\
\text { Pelmear }\end{array}$ \\
\hline $\begin{array}{l}\text { A } \\
\text { B }\end{array}$ & 19 & $\begin{array}{l}\text { No symptom } \\
\text { Tingling or numbness, OT/ON } \\
\text { or both. No } \\
\text { Raynaud's } \\
\text { phenomenon } \\
\text { Raynaud's } \\
\text { phenomenon }\end{array}$ & $\begin{array}{l}\text { O } \\
\text { C }\end{array}$ \\
\hline
\end{tabular}

is recorded. The cuff is then rapidly deflated, the hands remaining in the water. Fingertip and water temperature are recorded every 30 seconds for five minutes. The results are expressed in degrees Celsius as the $\mathrm{T}^{\circ}$ recorded three minutes after deflating the cuff minus the $T^{\circ}$ measured just before deflating the cuff. The highest $\mathrm{T}^{\circ}$ post deflating is also taken into account. Variations in water $\mathrm{T}^{\circ}$ are also considered.

\section{RELIABILITY STUDY}

Ten healthy male volunteers (mean age 24.8 years) working indoors were submitted randomly the same day to both tests once a week for ten weeks, with an interval of at least two hours between each test. The results were interpreted by a two way analysis of variance.

\section{VALIDITY STUDY}

Fifty two male subjects (mean age 26) exposed to hand arm vibration were examined: 48 lumbermen, two grinders, one carpenter, and one monumental mason. A medical and an occupational history were taken and subjects with Raynaud's disease or with secondary Raynaud's phenomenon due to a cause other than vibration were excluded. They were classified, according to their medical history, into three groups, based on Taylor and Pelmear's classification $^{7}$ (table 1).

Subjects were randomly submitted to both tests the same day, with an interval of at least two hours. The results were interpreted by a one way variance analysis, specificity and sensitivity tests, and a discriminant analysis.

\section{Results}

\section{RELIABILITY STUDY}

Similar results were observed with reactive hyperaemia at $15^{\circ} \mathrm{C}$ and $10^{\circ} \mathrm{C}$ and with cold water. Large variations over the ten weeks were shown by each volunteer (fig 1).

The two way analysis of variance (table 2) showed large, statistically significant differences between the mean values for each subject but only minor, nonstatistically significant, differences between the mean values of each week were observed, this for both hands.

\section{VALIDITY STUDY \\ Cold water test}

The mean temperature of the three groups changed in

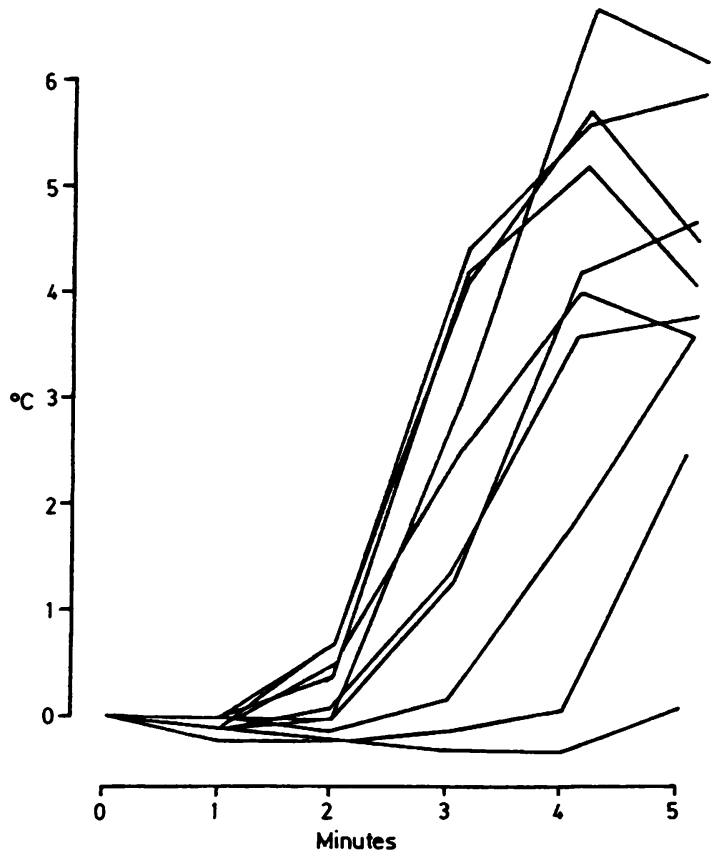

Fig 1 Reactive hyperaemia test: 10 rewarming curves for one subject (average, right hand).

Table 2 Cold water test: degree of significance of the differences between subjects and between weeks, left hand (two way analysis of variance, $N S: p \geqslant 0.05$ )

Time after hand withdrawal (minutes)

\begin{tabular}{llllllll}
\hline Differences & 1 & 3 & 5 & 7 & 10 & 15 & 20 \\
Between subjects & $<0.001$ & $<0.001$ & $<0.001$ & $<0.001$ & $<0.001$ & $<0.001$ & $<0.001$ \\
Between weeks & NS & NS & NS & NS & NS & NS & NS \\
\hline
\end{tabular}

NS $=$ Not significant. 
Fig 2 Cold water test: mean values ( $\pm 1 S E M)$, right hand, at five minutes.

Table 3 Cold water test: comparison at three different times of the average value of each group (one way analysis of variance)

\begin{tabular}{llll}
\hline $\begin{array}{l}\text { Measure at time } \\
(\text { minutes })\end{array}$ & $\begin{array}{l}\text { Right haind } \\
(p)\end{array}$ & $\begin{array}{l}\text { Left hand } \\
(p)\end{array}$ & $\begin{array}{l}\text { Worst finger } \\
(p)\end{array}$ \\
\hline 3 & 0.003 & 0.033 & 0.003 \\
5 & 0.003 & 0.026 & 0.003 \\
7 & 0.004 & 0.035 & 0.008 \\
\hline
\end{tabular}

agreement with clinical staging. The more advanced the disease, the less the rewarming (fig 2). The differences were statistically significant at different times (table 3).

\section{Reactive hyperaemia test}

As for the cold water test, results conformed to clinical staging (fig 3) but were only statistically significant with a water bath cooled at $10^{\circ} \mathrm{C}$, not at $15^{\circ} \mathrm{C}$ (table 4).

Table 5 Discriminant analysis

\begin{tabular}{|c|c|c|c|}
\hline \multirow[t]{2}{*}{ Test } & \multirow[t]{2}{*}{ Chosen parameter(s) } & \multirow{2}{*}{$\begin{array}{l}\text { Whole collective } \\
\begin{array}{l}\text { Percentage of subjects correctly } \\
\text { classified }\end{array}\end{array}$} & \multirow{2}{*}{$\begin{array}{l}\text { Group B } \\
\begin{array}{l}\text { Percentage of subjects correctly } \\
\text { classified }\end{array}\end{array}$} \\
\hline & & & \\
\hline $\begin{array}{l}\text { Cold water, right hand } \\
\text { Cold water, left hand }\end{array}$ & $\begin{array}{l}\mathrm{T}^{\circ} \text { at } 7^{\prime} \\
\mathrm{T}^{\circ} \text { at } \mathbf{3}^{\prime}\end{array}$ & $\begin{array}{l}60 \\
54\end{array}$ & $\begin{array}{l}\mathbf{0} \\
\mathbf{0}\end{array}$ \\
\hline Cold water, both hands & $\begin{array}{l}\mathrm{T}^{\circ} \text { right hand at } 1^{\prime} \\
\mathrm{T}^{\circ} \text { left hand at } 3^{\prime} \\
\mathrm{T}^{\circ} \text { left hand at } 5^{\prime}\end{array}$ & 67 & 36 \\
\hline Reactive hyperaemia, both hands & $\begin{array}{l}\text { Worst finger, at } 3^{\prime}, 10^{\circ} \mathrm{C} \text { water } \\
\text { bath }\end{array}$ & 56 & $\mathbf{0}$ \\
\hline
\end{tabular}

Table 4 Reactive hyperaemia test: comparison at three minutes of the average value of each group (one way analysi of variance, $N S: p \geqslant 0.05$ )

Parameter Measure at time (minutes) $p$

Right hand $\left(15^{\circ} \mathrm{C}\right)$

Left hand $\left(15^{\circ} \mathrm{C}\right)$

Worst finger $\left(15^{\circ} \mathrm{C}\right)$

Right hand $\left(10^{\circ} \mathrm{C}\right)$

Left hand $\left(10^{\circ} \mathrm{C}\right)$

Worst finger $\left(10^{\circ} \mathrm{C}\right)$

$\begin{array}{ll}3 & \text { NS } \\ 3 & \text { NS } \\ 3 & \text { NS } \\ 3 & 0.01 \\ 3 & 0.03 \\ 3 & 0.03\end{array}$

Brubaker et al fixed an arbitrary limit of $0.2^{\circ} \mathrm{C}$ for digital rewarming, values less than this being consid- 3 . ered a pathological and those greater, a normal response. ${ }^{10}$ The population was separated into two, group $A$ on one side, and groups $B$ and $C$ on the $O$ other; the former being composed of healthy subjects would be expected to have a normal response, the 
latter a pathological one. The sensitivity was $73 \%$, the specificity $\mathbf{7 4 \%}$.

A discriminant analysis, using the SPSS program was calculated (table 5). Roughly $60 \%$ of the subjects fell into the right category, most of the subjects wrongly classified belonging to group $\mathbf{B}$.

\section{Discussion}

The reliability study has shown that the tests studied here can be useful on a group basis. Indeed, the mean values for the group did not differ significantly from one week to the next. But it has also shown that dispersion is important, not only between the mean values of each subject, but also within a subject, from week to week. Therefore, for an individual, their predicture power is low. This was confirmed by the validity study.

The discriminant analysis showed that only $60 \%$ of the subjects were correctly classified. Different assumptions may be put forward to explain that. Firstly, the subjects were classified according to medical history alone. Secondly, most subjects wrongly classified belong to group $\mathrm{B}$, which may be considered as a borderline between healthy and unhealthy subjects. Thirdly, it may be due to the inter and intraindividual scattering of the results, as shown in the reliability study.

Using Brubaker's criteria, the results were a little more convincing. But the disadvantage of this analysis is that it only allows two groups to be formed. Subjects in group B (OT/ON) were classified as suffering from VWF although whether they will develop Raynaud's phenomenon is not known.

It is concluded that these tests may be used for a group follow up but have little value in the evaluation of an individual.

\section{References}

${ }^{1}$ Hellstrøm B, Myhre K. A comparison of some methods of diagnosing Raynaud phenomena of occupational origin. $\mathrm{Br} \mathrm{J}$ Ind Med 1971;28:272-9.

2 Juul C, Nielsen SL. Locally induced digital vasospasm detected by delayed rewarming in Raynaud's phenomenon of occupational origin. Br J Ind Med 1981;38:87-90.

${ }^{3}$ Miyashita K, Shiomi S, Itoh N, Kasamatsu T, Iwata H. Epidemiological study of vibration syndrome in response to total hand-tool operating time. Br J Ind Med 1983;40:92-8.

${ }^{4}$ Okada A, Yamashita T, Nagano C, Ikeda T, Yachi A, Shibata S. Studies on the diagnosis and pathogenesis of Raynaud's phenomenon of occupational origin. Br J Ind Med 1971;28:353-7.

${ }^{5}$ Okada A, Yamashita T, Ikeda T. Screening test for Raynaud's phenomenon of occupational origin. Am Ind Hyg Assoc J 1972;33:476-82.

${ }^{6}$ Olsen N, Nielsen SL, Voss P. Cold response of digital arteries in chain saw operators. Br J Ind Med 1982;39:82-8.

${ }^{7}$ Taylor W, Pelmear PL. Vibration white finger in industry. New York: Academic Press, 1975.

${ }^{8}$ Fawer R. Pathologie professionnelle provoquée par les vibrations des marteaux piqueurs et des perforatrices. Lausanne: Thèse de médecine, 1977.

${ }^{9} \mathrm{Krähenbühl} \mathrm{B}$. Une méthode utile pour le diagnostic du phénomène de Raynaud: la suppression par le froid de l'hyperémie réactionnelle post-ischémique digitale. Schweiz Med Wochenschr 1977;107:1831-3.

${ }^{10}$ Brubaker RL, Mackenzie CJG, Eng PR, Bates DV. Vibration white finger disease among tree fellers in British Columbia. $J$ Occup Med 1983;25:403-8. 